\title{
The Difference of Angiopoietin-2 Levels between Dengue Hemorrhagic Fever Patients with Shock and without Shock
}

\author{
Rinang Mariko ${ }^{1,2^{\star}}$, Eryati Darwin ${ }^{3}$, Yanwirasti Yanwirasti ${ }^{4}$, Sri Rezeki Hadinegoro ${ }^{5}$ \\ ${ }^{1}$ Postgraduate Biomedical Science, Faculty of Medicine, Andalas University, Padang, Indonesia; ${ }^{2}$ Department of Pediatrics, \\ Faculty of Medicine, Andalas University, General Hospital of Dr M. Djamil, Padang, Indonesia; ${ }^{3}$ Department of Histology, \\ Faculty of Medicine, Andalas University, Padang, Indonesia; ${ }^{4}$ Department of Anatomy, Faculty of Medicine, Andalas \\ University, Padang, Indonesia; ${ }^{5}$ Department of Pediatrics, Faculty of Medicine, Indonesia University, Jakarta, Indonesia
}

\begin{abstract}
Citation: Mariko R, Darwin E, Yanwirasti Y, Hadinegoro SR. The Difference of Angiopoietin-2 Levels between Dengue Hemorrhagic Fever Patients with Shock and
without Shock. Open Access Maced J Med Sci. 2019 Jul 15; 7(13):2119-2122 https://di.org/10.3889/oamjms.2019.569 Keywords: Angiopoietin-2; Dengue Hemorrhagic Fever (DHF); Shock

*Correspondence: Rinang Mariko. Doctoral Student of Postgraduate Biomedical Science, Faculty of Medicin Andalas University, Padang, Indonesia; Department of Pediatrics, Faculty of Medicine, Andalas University/General Hospital of $\mathrm{Dr}$ M. Djamil, Padang,

Received: 10-Apr-2019; Revised: 22-Jun-2019; Accepted: 25-Jun-2019; Online first: 13-Jul-2019 Copyright: ( 2019 Rinang Mariko, Eryati Darwin, Yanwirasti Yanwirasti, Sri Rezeki Hadinegoro. This is an open-access article distributed under the terms of the International License (CC BY-NC 4.0)

Funding: This research did not receive any financial suppo

Competing Interests: The authors have declared that no competing interests exis
\end{abstract}

\begin{abstract}
BACKGROUND: Dengue infection is one of the problems in the national health sector in Indonesia because the incidence and mortality in Indonesia due to dengue infection is still very high. In 2005 Indonesia became the highest contributor to dengue infection in Southeast Asia (53\%) with 95.270 people and 1.298 deaths.

AIM: This study aims to analyse differences in angiopoietin-2 levels in dengue hemorrhagic fever (DHF) with and without shock.

METHODS: This study was a consecutive sampling design with the research subject was obtained based on the order of admission to the hospital — the serum Angiopoietin-2 levels using the ELISA method. The statistical test used is the independent $t$-test. The value of $p<0.05$ was said to be statistically significant.

RESULT: The result showed that the mean of Angiopoietin-2 levels in DHF patients with shock was higher than in DHF $(p<0.05)$.

CONCLUSION: This study concluded that there was a difference in the average level of Angiopoietin-2 among DHF patients with shock compared to without shock.
\end{abstract}

\section{Introduction}

Dengue infection is one of the problems in the national health sector in Indonesia because the incidence and mortality in Indonesia due to dengue infection is still very high. In 2005 Indonesia became the highest contributor to dengue infection in Southeast Asia (53\%) with a total of 95.270 people and 1.298 deaths [1]. Manifestations of bleeding, enlargement of the liver and increase in SGOT and SGPT were significantly more common in dengue shock syndrome (DSS) than in the DHF group [2], [3].

In dengue infection, the liver is also involved. Liver cell damage, in addition to the inflammatory process and the formation of antigen-antibody complexes, also because of the process of dengue infection. Infected hepatocytes increase the activity of SGOT and SGPT, release VEGF and reduce the synthesis of clotting factors [4], [5], [6]. Hepatomegaly in dengue infection results from the direct influence of the dengue virus on the liver. Data from previous studies also show that hepatomegaly plays an important role as a risk factor for severe dengue virus infection [7]. Angiopoietin-1 and Angiopoietin-2 have functions in maintaining vascular function and integrity. Angiopoietin-1 is reported to not only play a role in blood vessel stabilisation during angiogenesis but also plays a role in inhibiting vascular permeability and has anti-inflammatory effects [8]. m-RNA molecules Ang-1 expressed in per endothelial cells 
play a role in maintaining blood vessel stability, inhibiting plasma leakage, suppresses the expression of inflammatory genes and prevents recruitment and migration of leukocytes. Unlike the case of Ang-1, Ang-2 which is selectively expressed in endothelial cells when binding to the Tie 2 receptor will result in signalling disorders of Ang-1 / Tie 2 resulting in impaired vascular permeability [9], [10].

This study aims to analyse differences in angiopoietin-2 levels in dengue hemorrhagic fever with and without shock.

\section{Materials and Methods}

This study was an observational study with a comparative cross-sectional design. The angiopoietin2 examination was carried out in the Biomedical Laboratory, Faculty of Medicine, Andalas University, Padang.

\section{Study Population}

The study population was patients with dengue virus infection (DHF and DSS) who were hospitalised at Dr M. Djamil Central General Hospital, according to WHO 2011 criteria [11]. Subjects were part of the population that met the inclusion and exclusion criteria. The inclusion criteria were patients with dengue hemorrhagic fever who had received informed consent from parents to participate in the study with the age of 1-15 years. Exclusion criteria were patients suffering from other viral or bacterial infections based on clinical and laboratory examinations, receiving corticosteroid therapy, malnutrition and obesity.

\section{Examination of Angiopoietin-2 Levels}

Blood samples $\pm 2-3 \mathrm{cc}$ (which is checked in the critical phase) that were inserted into the serum tube were sent to the Biomedical Laboratory, Faculty of Medicine, Andalas University using media transport at $4^{\circ} \mathrm{C}$. Samples must be stored at freezing temperature if not checked directly after taking. Provide 8 strips for inspection. Dissolve serum and plasma with the Standard Diluent Buffer ratio 1:10. Then, add 25 ul Incubation Buffer to each sample. After that, add 100 ul Standard Diluent Buffer to the standard and add $100 \mathrm{ul}$ standard, controls, or sample to the appropriate microtiter tube. Pipette a solution of 50 ul biotinylated Hu Ang-2 Biotin Conjugate into each reagent plate. Mix for 30 seconds. Cover the plate with a cover plate and incubate for 2 hours at the temperature. Pull or pour the solution from the plate and separate the solution, and then wash 4 times (according to washing instructions). After that, add
100 ul HRP Streptavidin solutions for each sample except empty chromagen (according to instructions for reagent preparation and storage). Cover the plate with a cover plate and incubate for 30 minutes at room temperature. Pull or pour the solution from the plate and separate the solution and wash 4 times (according to washing instructions). Then, add 100\% stabilised chromogen in each case. The solution will turn blue. Incubate for 30 minutes at ambient room temperature and add 100 ul stop solution into each sample. Mix slowly. The solution will change colour to yellow. Then, read the absorbance at $450 \mathrm{~nm}$ on the readromagen device. The plot of results obtained into the standard.

\section{Statistical analysis}

Bivariate analysis was performed to see the difference in mean Angiopoietin-2 in DHF patients with shock and without shock. First, the data are analyzed using normality test to determine the normality of the data using the Shapiro Wilk test $(\mathrm{n}<$ 50 ), then followed by bivariate analysis, if the data is normally distributed then the analysis is done using the dependent test t-test, but if it is known to be not normally distributed then Mann-Whitney test was done with confident interval $(\mathrm{Cl}) 95 \%$ and $\alpha=0.05$. The conclusion of the test results if the value of $p \leq 0.05$ then $\mathrm{H}_{0}$ is rejected, meaning that there is a difference in the mean between the independent variables and the dependent variable.

\section{Research Ethics}

This study was already passed the ethics clearance and has been approved by the Ethics Committee of the Faculty of Medicine, Andalas University, Padang.

\section{Results}

The difference in the results of Ang-2 examination between dengue sufferers with shock compared to those without shock can be seen as follows.

Table 1: Differences in the results of Ang-2 examination between dengue sufferers with shock compared to without shock

\begin{tabular}{lccc}
\hline & \multicolumn{2}{c}{ DHF } & \\
\cline { 2 - 3 } Variable & $\mathrm{DSS}(\mathrm{n}=62)$ mean $\pm \mathrm{SD}$ & $\mathrm{DHF}(\mathrm{n}=48)$ mean $\pm \mathrm{SD}$ & p-value \\
\hline Ang-2 $(\mathrm{pg} / \mathrm{ml})$ & $739.66 \pm 55.21$ & $497.90 \pm 220.68$ & $0.036^{*}$ \\
\hline
\end{tabular}

Table 1 showed that the average level of Ang2 in DHF patients with shock $739.66 \pm 55.21 \mathrm{pg} / \mathrm{ml}$ while DHF $49790 \pm 220.68 \mathrm{pg} / \mathrm{ml}$. The results of statistical tests showed that there were differences in 
the mean levels of Ang-2 among DHF patients with shock compared to those without shock $(p<0.05)$.

\section{The cut-off point for Ang-2 levels as a predictor of dengue sufferers with shock}

The cut-off point of Ang-2 levels as a predictor of dengue patients with shock is shown in Figure 1.

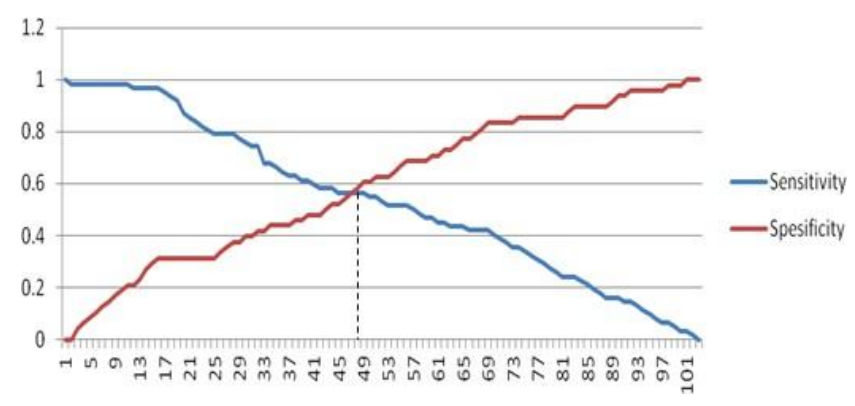

Figure 1: Point cut-off of Ang-2 levels as a predictor of DHF patients with shock

Figure 1 showed that the optimal cut-off points on the intersection of sensitivity and specificity lines to determine the cut-off point of Ang-2 levels as a predictor of DHF patients with shock is between point 48. The cut-off point of Ang-2 levels as a predictor of DHF patients with shock can be explained as follows subjects experienced DSS if the level of Ang-2 $\geq 427.56 \mathrm{pg} / \mathrm{ml}$ and subjects experience DHF if the level of Ang-2 $<427.56 \mathrm{pg} / \mathrm{ml}$.

The cut-off point of the sensitivity of Ang-2 levels was $56.4 \%$, and specificity was $58.3 \%$. Accuracy of cut-off point Ang-2 levels as predictors of dengue patients with shock is shown in Figure 2 below.

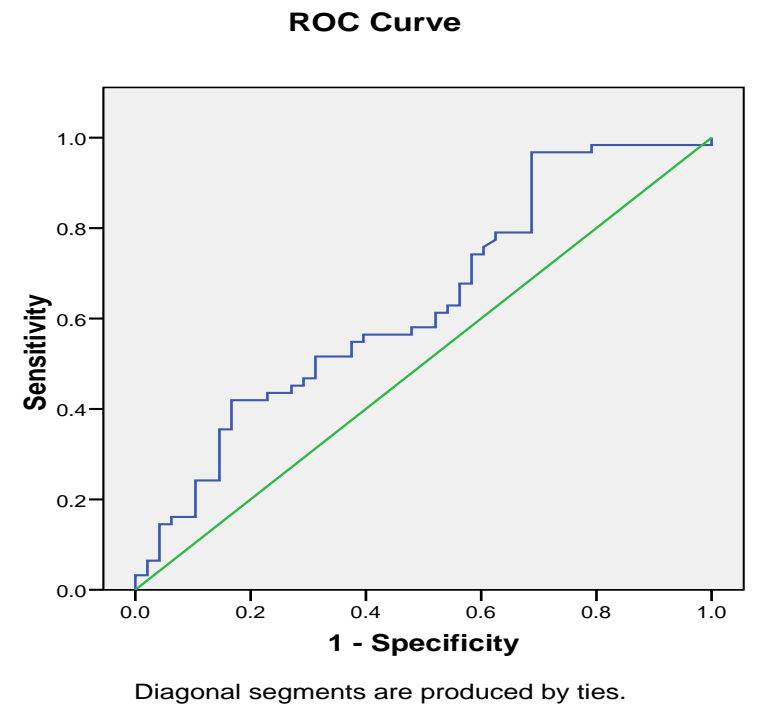

Figure 2: Accuracy of Cut-off point Ang-2 levels as predictors of DHF patients with shock

Based on the receiver operating curve analysis $(\mathrm{ROC})$ it is known that it has an area under the curve (AUC) of $63.4 \%$, which means that the cut- off points of Ang-2 which is $\geq 427.56 \mathrm{pg} / \mathrm{ml}$ have good accuracy in predicting DSS events.

\section{Discussion}

\section{The difference in the results of Ang-2 examination between dengue sufferers with shock compared to without shock}

Haematological parameters are considered as potential predictors, one of which is Angiopoietin. This study obtained Ang-2 levels of DHF patients with bigger shock than without shock $(p<0.05)$. This indicates that the higher the level of Ang-2, the more severe the disease due to dengue virus infection. The main complications of dengue infection mainly affect the vascular system and include plasma leakage, which will cause hypovolemic shock and potentially continue to become DSS. Angiopoietin can be considered a potential predictor for DSS in patients suffering from dengue infection. This is by the research conducted by Rampengan et al., (2015) who found that an increase in Ang-2 levels could trigger blood vessel instability, causing an increase in vascular permeability and plasma leakage. In this study, we found an increase in Ang-2 levels in DSS patients compared to DHF patients and dengue fever [12].

The mechanism for increasing Ang-2 levels and plasma leakage is a complex cascade. Binding of Ang-1 with the Tie-2 receptor via the phosphatidylinositol-3-kinase (PI3K) Akt pathway will cause blood vessel stability by recruiting pericytes into new blood vessels and maintaining intercellular contact. Ang-1 also has anti-inflammatory properties by regulating surface molecular adhesion. The binding of Ang-2 to the Tie-2 receptor can inhibit Ang-1 signalling to Tie-2 and increase blood vessel instability [13]. Mitchell et al. (2012) also found that DSS and DHF patients also had higher serum Ang-2 levels at baseline. Treatment compared to home care and compared to the control group. Release of Ang-2 from WPB is caused by activation of endothelial cells by proinflammatory cytokines, direct interaction of the virus with endothelial cells, the release of mast cell products and procoagulant factors such as thrombin [14].

Literature that has written normal levels of Ang-2 in children as long as the knowledge of researchers has not yet existed. The study by Rampengan et al., (2015) obtained the highest Ang-2 level on DSS compared to DHF and dengue fever with a result of 2,486.21 pg/dl in dengue fever, 3,194.95 $\mathrm{pg} / \mathrm{dl}$ in DHF and 4,005.32 pg/dl on DSS. In the research conducted by researchers concluded that if the level of Ang-2 $\geq 427.56 \mathrm{pg} / \mathrm{ml}$, then the subject will experience DSS (12). 
Increased levels of Ang-2 are also associated with death in sepsis. In a study by David et al. (2012), it was found that the concentration of Ang-2 has been reported as a predictor of mortality in critically ill patients. Ang-2 cut-off value of $2.86 \mathrm{ng} / \mathrm{mL}$ predicts the development of severe sepsis with a sensitivity of $75 \%$ and specificity of $56 \%$, the cut-off value of Ang-2 $3.56 \mathrm{ng} / \mathrm{mL}$ predicts the development of septic shock with a sensitivity of $73 \%$ and specificity $68 \%$, and the Ang-2 cut-off value of $5.1 \mathrm{ng} / \mathrm{mL}$ predicted mortality with $80 \%$ sensitivity and $76 \%$ specificity. This research is important because it can estimate the level of Ang-2 can be used as a biomarker in clinical practice so that it can be used in clinical decisionmaking regarding prognosis [15]. The cut-off point illustrates the accuracy in predicting DSS events. The cut-off point value is taken from the optimal intersection point of the sensitivity and specificity line intersections used in predicting the occurrence of shock in DHF patients.

This study concluded that there was a difference in the average level of Angiopoietin-2 among DHF patients with shock compared to without shock.

\section{References}

1. Mayetti M. Hubungan Gambaran Klinis dan Laboratorium Sebagai Faktor Risiko Syok pada Demam Berdarah Dengue. Sari Pediatri. 2016; 11(5):367-73.

https://doi.org/10.14238/sp11.5.2010.367-73

2. Parkash O, Almas A, Jafri SW, Hamid S, Akhtar J, Alishah H. Severity of acute hepatitis and its outcome in patients with dengue fever in a tertiary care hospital Karachi, Pakistan (South Asia). BMC gastroenterology. 2010; 10(1):43.

https://doi.org/10.1186/1471-230X-10-43 PMid:20459677 PMCid:PMC2881113

3. Supriatan M. Gangguan Fungsi Hati pada Demam Berdarah Dengue (Tesis). 2004. Semarang. Program Pendidikan Dokter Spesialis I Fakultas Kedokteran Universitas Diponegoro, 2004.

4. Pancharoen C, Rungasarannont A, Thisyakorn U. Hepatic dysfunction in dengue patients with various severity. J Med Assoc Thai. 2002; 85(1):S298-301.

5. Lin CF, Wan SW, Chen MC, Lin SC, Cheng CC, Chiu SC, et al.
Liver injury caused by antibodies against dengue virus nonstructural protein 1 in a murine model. Lab Invest. 2008; 233(4):401-408. https://doi.org/10.1038/labinvest.2008.70 PMid:18679379

6. Wahid SF, Sanusi S, Zawawi MM, Ali RA. A comparison of the pattern of liver involvement in dengue hemorraghic fever with classic dengue fever. Southeast Asian J Trop Med Public Health. 2000; 31(2):259-263.

7. Ledika MA, Setiabudi D, Dhamayanti M. Association between clinical profiles and severe dengue infection in children in developing country. American Journal of Epidemiology and Infectious Disease. 2015; 3(3):45-49.

8. Siner JM, Bhandari V, Engle KM, Elias JA, Siegel MD. Elevated serum angiopoietin 2 levels are associated with increased mortality in sepsis. Shock. 2009; 31:348-353.

https://doi.org/10.1097/SHK.0b013e318188bd06 PMid:18791490

9. Kranidioti H, Orfanos SE, Vaki I, Kotanidou, Raftogiannis M, Dimopoulou I, et al. Angiopoetin 2 is increased in septic shock: evidence for the exixtence of a circulatory factor stimulating its release from human monocyte. Immunol Lett. 2009; 125:65-71. https://doi.org/10.1016/j.imlet.2009.06.006 PMid:19539650

10. Kumpers P, Lukasz A, David S, Horn R, Hafer C, FaulhaberWalter R, et al. Excess circulating angiopoetin-2 a strong predictor of mortality incritically ill medical patient. Clin Care. 2008; 12:147. https://doi.org/10.1186/cc7130 PMid:19025590 PMCid:PMC2646310

11. World Health Organization-Southeast Asia Regional Office. Comprehensive guidelines for prevention and control of dengue and dengue hemorraghic fever. India. WHO, 2011.

12. Rampengan NH, Daud D, Warouw S, Ganda LJ. Serum angiopoietin-2 as marker of plasma leakage in dengue viral infection. American Journal of Clinical and Experimental Medicine. 2015; 3(1):39-43. https://doi.org/10.11648/j.ajcem.20150301.15

13. Yuan HT, Khankin EV, Karumanchi A, Parikh SM. Angiopoetin 2 is a partial agonist/antagonist of Tie-2 signaling in the endothelium. Mol Cell Biol. 2009; 29:2011-2022.

https://doi.org/10.1128/MCB.01472-08 PMid:19223473 PMCid:PMC2663314

14. Mitchel M, van der Ven AJAM, Djamiatun K, Fijnheer R, de Groot P, Griffioen AW, et al. Imbalance of Angiopoietin 1 and Angiopoietin-2 in severe dengue and relationship with thrombocytopenia, endothelial activation and vascular stability. Am J Trop Hyg. 2012; 87(5):943-946.

https://doi.org/10.4269/ajtmh.2012.12-0020 PMid:22949515 PMCid:PMC3516273

15. David S, Mukherjee A, Ghosh CC, Yano M, Khankin EV, Wenger JB, et al. Angiopoietin-2 may contribute to multiple organ dysfunction and death in sepsis. Crit Care Med. 2012; 40:30343041. https://doi.org/10.1097/CCM.0b013e31825fdc31 PMid:22890252 PMCid:PMC3705559 